\title{
PENGARUH DAY OF THE WEEK EFFECT TERHADA RETURN SAHAM PADA PERUSAHAAN YANG TERGABUNG DALAM JAKARTA ISLAMIC INDEX (JII)
}

\author{
Iswadi $^{1}$, Nurul Hafni ${ }^{2}$ \\ ${ }^{1,2}$ Prodi Akuntansi Fakultas Ekonomi dan Bisnis Universitas Malikussaleh Lhokseumawe \\ iswadi@unimal.ac.id
}

\begin{abstract}
This study aims to examine the effect of day of the week effect on the stock returns in the Jakarta Islamic Index (JII) in the period Desember 2017-May 2017. The data used in this study are secondary data obtained from www.yahoo.finance.com. The sample in this study are all compinies incorporated in the Jakarta Islamic Index as many as 30 companies. This study used multiple linear regression tests with dummy variables. The results of the study partially indicate that trading days on Thursday sifnificantly influence JII stock returns which can be seen from a significant value of 0,009. So, it can be concluded that day of the week effect on stock return in the jakarta islamic index (JII).
\end{abstract}

Keywords : Day Of The Week Effect, Stock Return, Jakarta Islamic Index

\section{PENDAHULUAN}

Pasar modal merupakan suatu mekanisme ekonomi dengan aktivitas perdagangan surat berharga yang memungkinkan perusahaan-perusahaan untuk mendapatkan keuntungan melalui transaksi jual beli sekuritas. Pasar modal pada dasarnya harus bersifat likuid dan efisien agar menarik para pihak yang kelebihan dana (lenders) serta pihak yang membutuhkan dana (borrowers) untuk bertransaksi. Pasar modal dikatakan likuid apabila pembeli dan penjual bisa melangsungkan transaksi jual beli sekuritas dengan cepat, sedangkan disebut efisien bila harga sekuritas mencerminkan nilai yang sesungguhnya dari perusahaan.

Konsep efisiensi pasar modal hingga sekarang masih sering menjadi sebuah perdebatan yang menarik dan terus ditelusuri di bidang keuangan. Hal tersebut dikarenakan adanya beberapa hasil penelitian yang di satu sisi memberikan bukti-bukti empiris pendukung kebenaran konsep pasar efisien, tetapi di sisi lain juga ada penelitian yang menemukan penyimpangan terhadap konsep pasar efisien. Penyimpangan tersebut menunjukkan bahwa investor bisa meraih keuntungan dalam melakukan transaksi jual beli saham dengan menggunakan pertimbangan berdasarkan data masa lalu dengan tujuan memprediksi harga saham. Penyimpangan- penyimpangan tersebut selanjutnya disebut sebagai anomali pasar.

MenurutJones (2010) Anomali pasar merupakan teknik atau strategi yang bertentangan dengan pasar efesien. Anomali mengakibatkan pasar bergerak tidak secara acak sehingga investor dapat memprediksi pola pergerakan return. Menurut Alteza (2006) terdapat empat jenis anomali yang dikenal dalam keuangan yaitu anomali perusahaan (firm anomalies) anomali musiman (season anomalies), anomali peristiwa atau kejadian (event anomalies) dan anomali akuntansi (accounting anomalies). Fenomena yang termasuk dalam anomali musiman yaitu efek hari perdagangan (day of the week effect). Day of the week effect adalah anomali di mana perbedaan hari perdagangan berpengaruh terhadap pola return saham dalam satu minggu. Anomali menyebabkan investor dapat membuat pendugaan karena pergerakan harga saham terpola pada saat tertentu, sehingga tidak lagi bergerak secara random atau acak.

Day of the week effect merupakan anomali yang menyebabkan hari perdagangan mempengaruhi pola tingkat pengembalian saham (Trisnadi dan Sedana, 2016) Pada teori pasar efisien menyatakan bahwa return saham tidak berbeda pada setiap hari perdagangan, namun fenomena day of the week effect menyatakan bahwa terdapat perbedaan return untuk masing-masing hari perdagangan dalam satu minggu. 
Return signifikan negatif biasanya terdapat pada hari perdagangan Senin, sementara return yang positif terdapat pada hari perdagangan lain selain Senin dan kenaikan return signifikan positif terjadi pada hari Jumat. Anomali ini adalah salah satu bentuk pengujian prediktabilitas return untuk menunjukan adanya return yang lebih rendah atau tinggi di suatu periode tertentu.

Penelitian yang dilakukan oleh Lakonishok dan Maberly (1990) dalam Prasetyo (2016) menemukan bahwa tingkat pengembalian pada hari Senin negatif dikarenakan investor meningkatkan transaksi dengan melakukan penjualan saham pada hari Senin, karena pada hari Jumat investor tidak sempat melakukan transaksi penjualan. Tingkat pengembalian negatif hari Senin yang dikemukakan oleh Damodaran (1989) dikarenakan perusahaan emiten mengumumkan berita buruk (bad news) pada menjelang penutupan hari Jumat sehingga mengakibatkan tingkat pengembalian negatif pada hari Senin. Kecenderungan adanya return negatif pada hari Senin lebih banyak ditentukan oleh faktor psikologis, dimana faktor tersebut menyebabkan adanya perilaku kurang rasional dan keputusan ekonom akan lebih banyak dipengaruhi oleh faktor emosi, perilaku psikologis, dan hasrat (mood) investor.

\section{TINJAUAN PUSTAKA}

\section{Pengertian Saham}

Menurut Anoraga (2006:54) saham merupakan surat berharga sebagai bukti penyertaan atau kepemilikan individu maupun institusi dalam suatu perusahaan. Saham berwujud selembar kertas yang menerangkan bahwa pemilik kertas adalah pemilik perusahaan yang menerbitkan surat berharga tersebut. Porsi kepemilikan ditentukan oleh seberapa besar pernyataan yang ditanamkan diperusahaan tersebut.Menurut Porman (2007:1), saham adalah bukti penyertaan modal pada suatu perusahaan, dengan membeli saham perusahaan, berarti pemodal menginvestasikan modal/dana yang nantinya akan digunakan oleh pihak manajemen untuk membiayai kegiatan operasional perusahaan.

\section{Return Saham}

Return adalah pendapatan yang dinyatakan dalam persentase dari modal awal investasi. Pendapatan investasi dalam saham ini merupakan keuntungan yang diperoleh dari jual beli saham, dimana jika untung disebut capital gain dan jika rugi disebut capital loss. Menurut Jogiyanto (2003:109) Return merupakan hasil yang diperoleh dari investasi. Return dapat berupa return yang sudah direalisasi yang sudah terjadi atau return ekspektasi yang belum terjadi tetapi diharapkan akan terjadi dimasa yang akan datang.Return sesungguhnya merupakan return yang terjadi pada waktu ke-t yangmerupakan selisih harga sekarang relatif terhadap harga sebelumnya. Returnsaham (Ri,t) sesungguhnya diperoleh dari harga saham harian sekuritas i pada periode $t(P i, t) d i$ kurangi harga saham harian sekuritas i pada periode $\mathrm{t}-1$ (Pi,t-1), dibagi harga saham harian sekuritas $\mathrm{i}$ pada periode $\mathrm{t}-1$ (pi,t-1), lebih jelasnya dapat dirumuskan sebagai berikut Jogiyanto (2010:207),

$\mathrm{R}_{\mathrm{i}, \mathrm{t}}=\frac{\mathrm{Pi}, \mathrm{t}-\mathrm{pi}, \mathrm{t}-1}{\mathrm{Pi}, \mathrm{t}-1}$

Keterangan,

$\mathrm{R}_{\mathrm{i}, \mathrm{t}}=$ Retur saham harian sekuritas $\mathrm{i}$ pada

periode $\mathrm{t}$

$\mathrm{P}_{\mathrm{i}, \mathrm{t}}=$ Harga saham harian sekuritas $\mathrm{i}$ pada periode $\mathrm{t}$

$\mathrm{P}_{\mathrm{i}, \mathrm{t}-1}=$ Harga saham harian sekuritas $\mathrm{i}$ pada periode $\mathrm{t}$

\section{Day Of The Week Effect}

The day of the week effect merupakan salah satu contoh anomali musiman (seasional anomalies) yang termasuk kedalam callendar effect. Adanya anomali kalender menyebabkan investor tidak dapat mengambil keuntungan yang tidak normal. Namun dengan adanya anomali . investor dapat mendapatkan keuntungan yang tidak normal melebihi nilai risiko sekuritas yang ada

Menurut Alteza (2006) The Day of The Week Effectadalah anomali di mana perbedaan hari perdagangan berpengaruh terhadap pola return saham dalam satu minggu Biasanya return yang signifikan negatif terjadi pada hari Senin, sedangkan return positif terjadi pada hari-hari lainnya. Fenomena ini merupakan bagian dari pengujian prediktabilitas return memakai pola musiman (seasonality) yang memperlihatkan adanya return saham yang lebih tinggi atau lebih rendah pada periode tertentu.

Day of the week effect adalah penyimpangan terhadap konsep pasar efisien dan termasuk ke dalam anomali musiman. Day of the week effect merupakan perbedaan return antara hari Senin dengan hari-hari lainnya dalam seminggu secara signifikan. Return yang signifikan negatif terjadi pada hari Senin, sedangkan return positif terjadi pada hari-hari lainnya. Day of the week effect merupakan anomali yang menyebabkan hari perdagangan memengaruhi pola tingkat pengembalian saham (Trisnadi dan Sedana, 2016). Artinya, ada suatu perbedaan return pada hari-hari tertentu dalam seminggu. Return signifikan negatif biasanya terdapat pada hari perdagangan Senin, sementara return yang signifikan positif terdapat pada hari perdagangan lain selain Senin. Anomali ini adalah salah satu bentuk pengujian prediktabilitasreturn untuk menunjukkan 
adanya return saham yang lebih rendah atau tinggi di suatu periode tertentu.

\section{Kerangka Konseptual}

Untuk menanggapi permasalahan-permasalah yang dihadapi peneliti ada baiknya untuk mengkaji beberapa teori dan hasil dari penelitian yang terdahulu yang relavan sehingga dapat untuk di pertanggung jawabkan secara ringkas dengan kerangka pemikiran yang mendasari ini semua. Adapun yang menjadi kerangka pemikiran dalam penelitian ini dapat di jelaskan bahwa return saham (Y) di pengaruhi oleh variable Monday effect $\left(\mathrm{X}_{1}\right)$, rogalski $\left(\mathrm{X}_{2}\right)$.Variable penelitian pada dasarnya adalah suatu hal yang berbentuk apa saja yang di tetapkan oleh peneliti untuk dianalisa sehingga di peroleh kesimpulan tentang hal yang di teliti, kemudian ditarik kesimpulannya (Ghozali, 2010)

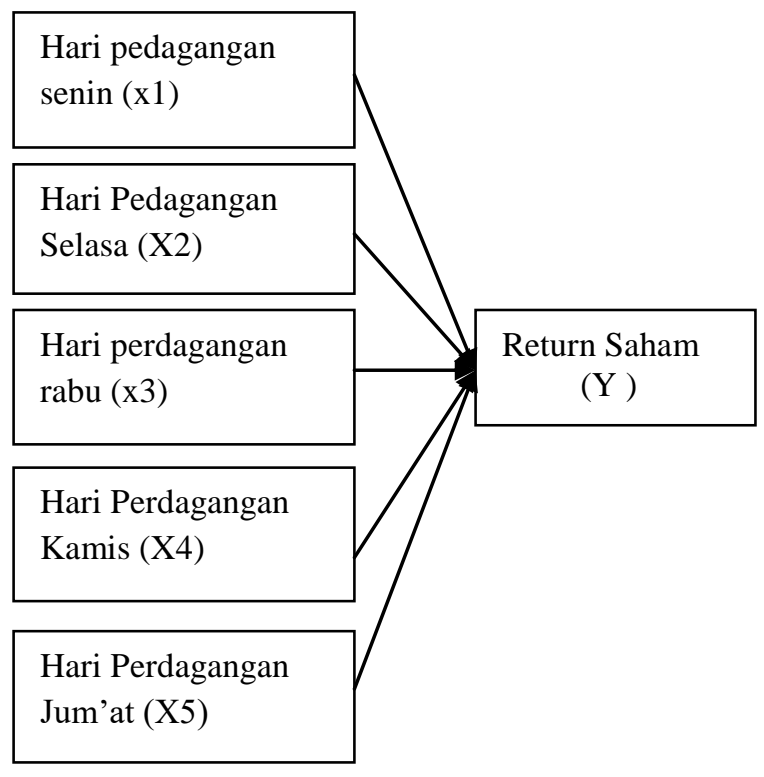

Gambar 1. Kerangka konseptual

\section{Hipotesis}

Hipotesis merupakan jawaban sementara terhadap rumusan masalah penelitian, oleh karena itu rumusan masalah penelitian biasanya disusun dalam bentuk kalimat pertanyaan. dikatakan sementara, karena jawaban yang diberikan baru didasarkan pada teori yang relevan. Belum didasarkan pada fakta-fakta yang empiris yang diperoleh melauli pengumpulan data. Adapun hipotesis dalam penelitian ini adalah :

$\mathrm{H}_{01}=$ diduga bahwa hari perdagangan Senin tidak berpengaruh terhadap return saham pada perusahaan yang tergabung dalam Jakarta Islamic index (JII)

$\mathrm{H}_{\mathrm{a} 1}=$ diduga bahwa hari perdagangan Senin berpengaruh terhadap return saham pada perusahaan yang tergabung dalam Jakarta Islamic index (JII)

$\mathrm{H}_{02}=$ diduga bahwa hari perdagangan Selasa tidak berpengaruh terhadap return saham pada perusahaan yang tergabung dalam Jakarta Islamic index (JII)

$\mathrm{H}_{\mathrm{a} 2}=$ diduga bahwa hari perdagangan Selasa berpengaruh terhadap return saham pada yang tergabung dalam Jakarta Islamic index (JII )

$\mathrm{H}_{03}=$ diduga bahwa hari perdagangan Rabu tidak berpengaruh terhadap return saham pada perusahaan yang tergabung dalam Jakarta Islamic index (JII).

$\mathrm{H}_{\mathrm{a} 3}=$ diduga bahwa hari perdagangan Rabu berpengaruh terhadap return saham pada perusahaan yang tergabung dalam Jakarta Islamic index (JII )

$\mathrm{H}_{04}=$ diduga bahwa hari perdagangan Kamis tidak berpengaruh terhadap return saham pada perusahaan yang tergabung dalam Jakarta Islamic index (JII)

$\mathrm{H}_{\mathrm{a} 4}=$ diduga bahwa hari perdagan Kamis berpengaruh terhadap return saham pada perusahaan yang tergabung dalam Jakarta Islamic index (JII )

$\mathrm{H}_{05}=$ diduga bahwa hari perdagangan jum'at tidak berpengaruh terhadap return saham pada perusahaan yang tergabung dalam Jakarta Islamic index (JII )

$\mathrm{H}_{\mathrm{a} 5}=$ diduga bahwa hari perdagan jum'at berpengaruh terhadap return saham pada perusahaan yang tergabung dalam Jakarta Islamic index (JII)

\section{METODE PENELITIAN}

\section{Objek dan Lokasi Penelitian}

Objek dalam penelitian ini adalah day of the week effect sebagai variabel independen dan return saham sebagai variabel dependen. Penelitian ini dilakukan pada saham yang tergabung dalam Jakarta Islamic Index (JII) di BEI periode Desember 2016 sampai Mei 2017 yang diakses melalui www.yahoofinance.com. Metode yang digunakan pada penelitian ini adalah penelitian komperatif yaitu untuk mengetahui perbedaan return saham pada setiap hari perdagangan.

\section{Populasi dan Sampel Populasi}


Menurut Sugiono (2008:80) Populasi adalah wilayah generaliasai yang terdiri atas objek/subjek yang mempunyai kuantitas dan karakteristik tertentu yang ditetapkan oleh peneliti untuk dipelajari dan kemudian ditarik kesimpulannya. Populasi dari penelitian ini adalah perusahaan-perusahaan yang termasuk dalam kelompok Jakarta Islamic Index (JII) periode Desember 2016 sampai Mei 2017 yang berjumlah 30 perusahaan.

\section{Sampel}

Menurut Sugiono (2008:81) sampel adalah bagian dari jumlah dan karakteristik yang dimiliki oleh populasi. Sampel dalam penelitian ini dipilih dengan menggunakan sampel jenuh. Sugiyono (2012:85)mengatakan bahwa sampling jenuh adalah teknik penentuan sampel bila semua anggota populasi digunakan sebagai sampel.

\section{Teknik Pengumpulan Data}

Metode pengumpulan data yang digunakan dalam penelitian ini adalah metode dokumentasi. Data yang digunakan adalah data sekunder yang berkaitan dengan data harga penutupan saham harian pada perusahaan sampel selama periode 1 Desember 2016 -31 Mei 2017 . Data tersebut adalah dokumentasi tertulis yang diperoleh dari www.idx.co.id dan www.finance.yahoo.com.

\section{HASIL PENELITIAN DAN PEMBAHASAN}

\section{Hasil Pengujian \\ Statistik Deskriptif}

Analisis deskriptif merupakan suatu metode dimana data-data yang dikumpulkan dan dikelompokkan kemudian dianalisis dan diinterpretasikan secara objektif sehingga memberikan informasi dan gambaran mengenai topik yang dibahas. Statistik deskriptif digunakan untuk memberikan gambaran / deskripsi mengenai karakteristik variabel. Variabel yang digunakan dalam penelitian ini yaitu variabel the day of the week effect. Pengamatan terhadap 30 saham perusahaan yang dijadikan sampel pada penelitian ini, diperoleh hasil rata-rata pendapatan harian pada periode Desember 2016-Mei 2017, sebagaimana disajikan berikut:

Tabel 1

Descriptive Statistics

\begin{tabular}{|l|r|r|r|r|r|}
\hline & $\mathrm{N}$ & \multicolumn{1}{|c|}{ Minimum } & \multicolumn{1}{c|}{ Maximum } & \multicolumn{1}{c|}{ Mean } & \multicolumn{1}{c|}{ Std. Deviation } \\
\hline SENIN & 30 & -.01412 & .00937 & -.0015453 & .00686334 \\
SELASA & 30 & -.01784 & .01336 & -.0033092 & .00757648 \\
RABU & 30 & -.00568 & .00945 & .0005457 & .00295149 \\
KAMIS & 30 & -.01206 & .03791 & .0035599 & .01259570 \\
JUMAT & 30 & -.00534 & .00641 & .0005667 & .00305934 \\
& & & &
\end{tabular}

Tabel 1 Descriptive Statistics

\begin{tabular}{|l|r|r|r|r|r|}
\hline & \multicolumn{1}{|c|}{$\mathrm{N}$} & \multicolumn{1}{|c|}{ Minimum } & \multicolumn{1}{c|}{ Maximum } & \multicolumn{1}{c|}{ Mean } & \multicolumn{1}{c|}{ Std. Deviation } \\
\hline SENIN & 30 & -.01412 & .00937 & -.0015453 & .00686334 \\
SELASA & 30 & -.01784 & .01336 & -.0033092 & .00757648 \\
RABU & 30 & -.00568 & .00945 & .0005457 & .00295149 \\
KAMIS & 30 & -.01206 & .03791 & .0035599 & .01259570 \\
JUMAT & 30 & -.00534 & .00641 & .0005667 & .00305934 \\
Valid N & 30 & & & & \\
(listwise) & & & & & \\
\hline
\end{tabular}

Dalam tabel 1, jumlah data saham yang digunakan untuk menghitung return harian dalam satu periodedari 30 perusahaan ada 150return. Dari 150 data return diatas, hariSenin dan Selasa memiliki nilai rata- rata negatif sedangkan hari lainnya memiliki nilai rata- rata positif. Rata-rata return terendah terjadi pada hari Selasa dengan nilai mean 0.0033092 , sedangkan rata-rata return tertinggi terjadi pada hari Kamis dengan nilai mean 0,0035599.Nilai minimum dan maksimum terendah menunjukkan return terendah selama penelitian terjadi pada hari selasa, yaitu sebesar $-0,01784$ dan nilai return tertinggi selama periode penelitian terjadi pada hari Kamis yaitu sebesar 0.03791 .

\section{Hasil Uji Asumsi Klasik Uji Normalitas}

Metode yang digunakan dalam uji normalitas adalah normal probability plot yang membandingkan distribusi kumulatif dari distribusi normal sehingga membentuk satu garis diagonal. Uji normalitas dapat diketahui dengan melihat alur penyebaran titik pada sumbu diagonal dari grafik. Distribusi data dikatakan normal apabila titik yang titik yang menggambarkan data sesungguhnya mengikuti garis diagonal (Ghazali,2011)

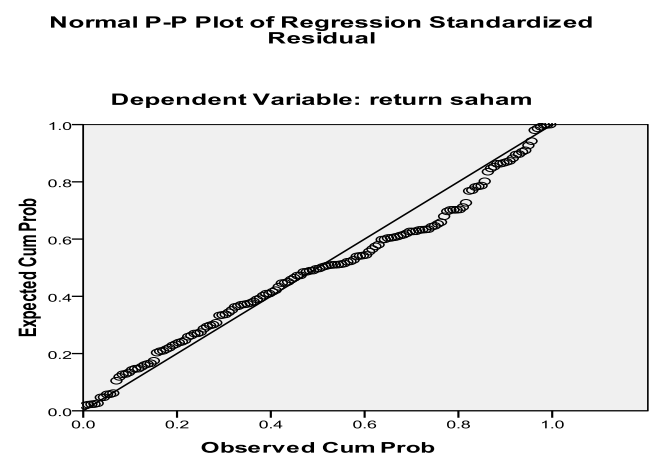

Gambar 2 grafik probability plot

Berdasarkan gambar diatas dapat diketahui bahwa titik-titik menyebar disekitar garis diagonal dan penyebarannya mengikuti arah garis diagonal 
tersebut, maka dapat disimpul bahwa data terdistribusi normal sehingga uji terpenuhi.

\section{Uji Multikolinieritas}

Uji multikolinieritas bertujuan untuk mengetahui apakah dalam suatu regresi ditemukan adanya korelasi antar variabel independen. Untuk mendeteksi ada tidaknya multikoliniearitas dalam model regresi dapat dilihat daritolerance value atau variance nnflation factor (VIF). Batas VIF adalah 10 apabila nilai VIF lebih besar dari pada $10(V I F>10)$ maka terjadi multikolinearitas.

Tabel.2

hasil uji multikolinearitas

\begin{tabular}{|ll|l|l|}
\hline \multirow{2}{*}{ Model } & \multicolumn{2}{|l|}{ Collinearity Statistics } \\
\cline { 2 - 4 } & Tolerance & VIF \\
\hline 1.025 & SELASA & 1.600 \\
& RABU & .625 & 1.600 \\
& KAMIS & .625 & 1.600 \\
& & 1.600 \\
\hline
\end{tabular}

Tabel diatas menunjukkan semua variabel dummy yaitu Dsel, Drab, Dkam, dan Djum memiliki nilai variance inflation factor (VIF) lebih kecil dari 10. Jadi dapat disimpulkan bahwa tidak ada multikolinearitas antar variabel independen dalam model regresi.

\section{Uji Autokorelasi}

Uji autokorelasi bertujuan untuk menguji apakah dalam model regresi linear ada korelasi antara kesalahan pengganggu periode $\mathrm{t}$ dengan kesalahan periode t-1 atau sebelumnya (Ghozali,2006:99).

Tabel 3

Hasil Uji Autokorelasi

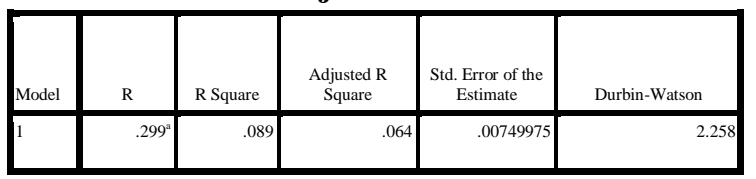

a. Predictors: (Constant), JUMAT, KAMIS,

RABU, SELASA

b. Dependent Variable: return saham

Berdasarkan hasil pengujian dengan program SPSS, nilai Durbin Watson diperoleh (DW) sebesar2.258. Berdasarkan tabel Durbin Watson, dengan tingkat signifikansi sebesar 0,05 , jumlah data (n) sebanyak 30, jumlah variabel independen (k) sebanyak 4, maka diperoleh nilai dL 1,1426dan $\mathrm{dU}=$ 1,7386 . Nilai $(4-\mathrm{dL})=2,8574$ dan nilai $(4-\mathrm{dU})=$ 2,2614 . Nilai DW sebesar 2.258 berada di antara nilai batas atas dU dan nilai (4-dU) atau dU < DW < 4-dU, sehingga pada model regresi tidak terjadi autokorelasi positif maupun negatif pada modelregresi

\section{Uji Heterokedastisitas}

Heteroskedastisitas merupakan kondisi dimana varian tidak konstan. Uji heteroskedastisitas dilakukan untuk mendeteksi penyebaran variabelvariabel serta dapat menguji apakah dalam sebuah model regresi terjadi ketidaksamaan varian dari residual satu pengamatan ke pengamatan yang lain (Ghozali, 2011).

Tabel 4

Hasil Uji Heterokedastisitas

\begin{tabular}{|c|c|c|c|c|c|c|c|c|}
\hline & & & SENIN & $\begin{array}{c}\text { SELAS } \\
\text { A }\end{array}$ & RABU & $\begin{array}{c}\text { KAMI } \\
\mathrm{S}\end{array}$ & JUMAT & $\begin{array}{c}\text { Unstand } \\
\text { ardized } \\
\text { Residual }\end{array}$ \\
\hline \multirow{18}{*}{$\begin{array}{l}\text { Spearma } \\
\text { n's rho }\end{array}$} & \multirow{3}{*}{ SENIN } & $\begin{array}{l}\text { Correlation } \\
\text { Coefficient }\end{array}$ & 1.000 & $-.250^{\prime \prime \prime}$ & \begin{tabular}{|l|}
$.250^{n+1}$ \\
\end{tabular} & $-.250^{\prime \prime \prime}$ & $-.250^{\prime \prime}$ & .011 \\
\hline & & Sig. (2-tailed) & & .002 & .002 & .002 & .002 & .896 \\
\hline & & $\mathrm{N}$ & 150 & 150 & 150 & 150 & 150 & 150 \\
\hline & \multirow[t]{3}{*}{ SELASA } & $\begin{array}{l}\text { Correlation } \\
\text { Coefficient }\end{array}$ & $-.250^{-\prime}$ & 1.000 & $-.250^{\prime \prime}$ & $-.250^{\circ}$ & $-.250^{\circ}$ & .004 \\
\hline & & Sig. (2-tailed) & .002 & & .002 & .002 & .002 & .959 \\
\hline & & $\mathrm{N}$ & 150 & 150 & 150 & 150 & 150 & 150 \\
\hline & \multirow[t]{3}{*}{ RABU } & $\begin{array}{l}\text { Correlation } \\
\text { Coefficient }\end{array}$ & $-.250^{\circ}$ & $-.250^{*+1}$ & 1.000 & $-.250^{* *}$ & $-.250^{\circ+1}$ & .033 \\
\hline & & Sig. (2-tailed) & .002 & .002 & & .002 & .002 & .691 \\
\hline & & $\mathrm{N}$ & 150 & 150 & 150 & 150 & 150 & 150 \\
\hline & \multirow[t]{3}{*}{ KAMIS } & $\begin{array}{l}\text { Correlation } \\
\text { Coefficient }\end{array}$ & $-.250^{-"}$ & $-.250^{\prime \prime}$ & $-.250^{-1}$ & 1.000 & $-.250^{\prime \prime \prime}$ & -.086 \\
\hline & & Sig. (2-tailed) & .002 & .002 & .002 & & .002 & .294 \\
\hline & & $\mathrm{N}$ & 150 & 150 & 150 & 150 & 150 & 150 \\
\hline & \multirow[t]{3}{*}{ JUMAT } & $\begin{array}{l}\text { Correlation } \\
\text { Coefficient }\end{array}$ & $-.250^{-1}$ & $-.250^{\prime \prime \prime}$ & \begin{tabular}{|c|}
$.250^{\prime \prime}$ \\
\end{tabular} & $-250^{\prime \prime}$ & 1.000 & .038 \\
\hline & & Sig. (2-tailed) & .002 & .002 & .002 & .002 & & .640 \\
\hline & & $\mathrm{N}$ & 150 & 150 & 150 & 150 & 150 & 150 \\
\hline & \multirow[t]{3}{*}{$\begin{array}{l}\text { Unstandar } \\
\text { dized } \\
\text { Residual }\end{array}$} & $\begin{array}{l}\text { Correlation } \\
\text { Coefficient }\end{array}$ & .011 & .004 & .033 & -.086 & .038 & 1.000 \\
\hline & & Sig. (2-tailed) & .896 & .959 & 691 & .294 & .640 & \\
\hline & & $\mathrm{N}$ & 150 & 150 & 150 & 150 & 150 & 150 \\
\hline
\end{tabular}

**. Correlation is significant at the 0.01 level (2tailed).

Tabel diatas menunjukkan semua variabel dummy yaitu Dsel, Drab, Dkam, dan Djum memiliki nilai signifikan lebih besar dari pada 0,05. Jadi dapat disimpulkan bahwa penelitian ini terbebas dari masalah heterokedastisitas. 


\section{Pengujian Hipotesis}

Analisis Regresi Linear Berganda

Dalam penelitian ini uji regresi yang digunakan adalah uji regresi linear berganda dengan variabel dummy sebagai variabel independen. Variabel dummy

Tabel 5

Hasil Regresi linear Berganda

\begin{tabular}{|c|c|c|c|c|c|}
\hline \multirow[b]{2}{*}{ Model } & \multicolumn{2}{|c|}{ Unstandardized Coefficients } & \multirow{2}{*}{$\begin{array}{c}\begin{array}{c}\text { Standardized } \\
\text { Coefficients }\end{array} \\
\text { Beta }\end{array}$} & & \\
\hline & B & Std. Error & & $\mathrm{t}$ & Sig. \\
\hline (Constant) & -.002 & .001 & & -1.129 & .261 \\
\hline SELASA & -.002 & .002 & -.091 & -.911 & .364 \\
\hline RABU & . 002 & .002 & .108 & 1.080 & .282 \\
\hline KAMIS & .005 & .002 & .264 & 2.636 & .009 \\
\hline JUMAT & .002 & .002 & .109 & 1.091 & .277 \\
\hline
\end{tabular}

a. Dependent Variable: returnsaham

Tabel 6

Excluded Variables

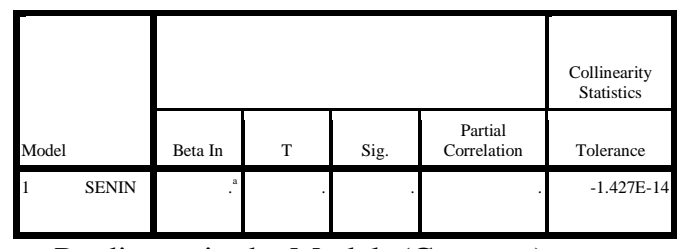

a. Predictors in the Model: (Constant),

JUMAT, KAMIS, RABU, SELASA

b. Dependent Variable: return saham

Dari hasil analisis di atas dapat dibuat persamaan regresi sebagai berikut :

$\mathrm{Rt}=-\mathbf{0 , 0 0 2}-0,002 \mathrm{Dsel}+\mathbf{0 , 0 0 2 D r a b}+0,005$ Dkam $+0,002$ Djum

Dalam hal ini kategori hari Senin digunakan dianggap sebagai kategori excluded yaitu variabel yang dikeluarkan dari analisis karena memiliki nilai yang ekstrim yaitu nilai tolerance dari variabel hari Senin sangat kecil dan bernilai negatif, kategori ini digunakan sebagai referensi untuk membandingkan kategori hari lainnya. Nilai konstanta -0,002 merupakan nilai rata-rata imbal hasil (return) hari Senin (excluded kategori). Jadi imbal hasil rata-rata pada hari Senin sebesar-0,002. sedangkan koefisien pada dummy variabel sering disebut dengan differential interceptcoefficients oleh karena adalah variabel yang digunakan untuk mengkuantitatifkan variabel yang bersifat kualitatif (misal: jenis kelamin, ras, agama, perubahan kebijakan pemerintah, perbedaan situasi, dan lainlain). Dalam penelitian ini yang menjadi variabel dummy adalah lima hari perdagangan, yaitu Senin, Selasa, Rabu, Kamis, dan Jumat. Sementara variabel terikat (dependen) dalam penelitian ini adalah return saham. Berdasarkan hasil pengolahan data day of the week effect terhadap return saham diperoleh hasil regresi sebagai berikut :

koefisien ini menjelaskan seberapa besar nilai intercept yang mendapatkan nilai1 (included dummy) berbeda dari koefisien intercept excluded dummy (Ghozali, 2009 : 184).

Berdasarkan persamaan regresi, dapat dijelaskan halhal sebagai berikut:

1. Koefisien regresi hari Selasa sebesar 0,002 menerangkan bahwa saat terjadi perdagangan di hari Selasa, maka terdapat pengaruh negatif pada return saham di mana terdapat kecenderungan penurunan sebesar 0,2 persen.

2. Koefisien regresi hari Rabu sebesar 0,002 menerangkan bahwa saat terjadi perdagangan di hari Rabu, maka terdapat pengaruh positif pada return saham di mana terdapat kecenderungan kenaikan sebesar 0,2 persen.

3. Koefisien regresi hari Kamis sebesar 0,005 menerangkan bahwa saat terjadi perdagangan di hari Kamis, maka terdapat pengaruh positif pada return saham di mana terdapat kecenderungan kenaikan sebesar 0,5 persen.

4. Koefisien regresi hari Jum'at sebesar 0,002 menerangkan bahwa saat terjadi perdagangan di hari Jum'at, maka terdapat pengaruh positif pada return saham di mana terdapat kecenderungan kenaikan sebesar 0,2 persen.

\section{Pembuktian Hipotesis Uji t (Uji Parsial)}

Pengujian hipotesis dilakukan melalui regresi yang menggunakan program SPSS dengan membandingkan pengujian yang digunakan adalah dengan menggunakan ketentuan apabila $t$ hitung $>t$ tabel pada $\mathrm{a}=0,05$, maka diterima atau dengan kata lain terdapat pengaruh antara satu variabel independen terhadap variabel dependen. Tingkat signifikasi (sig t) masing-masing variabel independen dengan taraf sig $\mathrm{a}=0,05$. Berdasarkan Ghozali (2009), uji statistik $\mathrm{T}$ pada dasarnya digunakan untuk menunjukkan seberapa jauh variabel dependen atau independen secara individual dalam 
menerangkan variasi varibel dependen. Pengujian ini dilakukan untuk menguji variabel independen secara parsial dengan tingkat profitabilitas (a) $5 \%$.

Berdasarkan hasil pengolahan data day of the week effect terhadap return saham diperoleh hasil regresi sebagai berikut :

Tabel 7

\section{Hasil Uji T}

\begin{tabular}{|c|c|c|c|c|c|}
\hline \multirow[b]{2}{*}{ Model } & \multicolumn{2}{|c|}{ Unstandardized Coefficients } & \multirow{2}{*}{$\begin{array}{c}\begin{array}{c}\text { Standardized } \\
\text { Coefficients }\end{array} \\
\text { Beta }\end{array}$} & \multirow[b]{2}{*}{$\mathrm{t}$} & \multirow[b]{2}{*}{ Sig. } \\
\hline & B & Std. Error & & & \\
\hline (Constant) & -.002 & .001 & & -1.129 & .261 \\
\hline SELASA & -.002 & .002 & -091 & -.911 & .364 \\
\hline RABU & .002 & .002 & .108 & 1.080 & .282 \\
\hline KAMIS & .005 & .002 & .264 & 2.636 & .009 \\
\hline JUMAT & .002 & .002 & .109 & 1.091 & .277 \\
\hline
\end{tabular}

Tabel 4.8

Excluded Variables

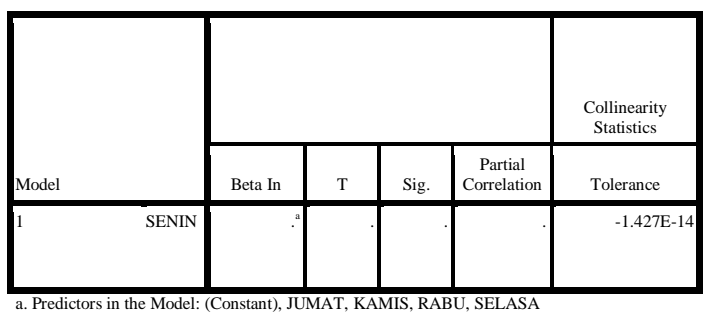

b. Dependent Variable: return saham

Dari hasil analisis pada tabel 4.7, dengan menggunakan tingkat kesalahan $\alpha=0,05$ dan degree of freedom $(\mathrm{n}-\mathrm{k})$, dimana $\mathrm{n}=30$ dan $\mathrm{k}=4$, diketahui nilai t tabel sebesar 1.70562

Adapun dari hasil perhitungan menunjukkan bahwa hari Seninadalah exclude variable, dari hasil uji t hanya variabel hari perdagangan Kamisyang berpengaruh secara signifikan terhadap return saham, sementara hari perdagangan Selasa, Rabu, dan Jumat tidak berpengaruh terhadap return saham.

Berikut ini penjelasan hasil uji t masingmasing variabel :

1. Hipotesis kedua yaitu variabel hari perdagangan selasa diketahui bahwa Nilai t hitung variabel Selasa sebesar $-0.911(\mathrm{t}$ hitung < t tabel) dan nilai signifikan 0.364> 0,05, maka secara parsial variabel hari perdagangan Selasa tidak berpengaruh terhadap Return Saham, sehingga dapat disimpulkan bahwa penelitian ini menolak $\mathrm{H}_{\mathrm{a} 2}$ dan menerima $\mathrm{H}_{02}$

2. Hipotesis ketiga yaitu variabel hari perdagangan Rabu diketahui bahwa Nilai t hitung variabel Rabu sebesar 1.080(t hitung $<\mathrm{t}$ tabel) dan nilai signifikan 0.282>0,05, maka secara parsial variabel hari perdagangan Rabu tidak berpengaruh terhadap Return Saham, sehingga dapat disimpulkan bahwa penelitian inimenolak $\mathrm{H}_{\mathrm{a} 3}$ dan menerima $\mathrm{H}_{03}$

3. Hipotesis keempat yaitu variabel hari perdagangan kamis diketahui bahwa Nilai t hitung variabel Kamis sebesar 2.636(t hitung $>\mathrm{t}$ tabel) dan nilai signifikan 0,009<0,05, maka secara parsial variabel hari perdaganganKamis berpengaruh secara signifikan terhadap Return Saham, jadi dapat disimpulkan bahwa penelitian ini menerima $\mathrm{H}_{\mathrm{a} 4}$ danmenolak $\mathrm{H}_{04}$

4. Hipotesis kelima yaitu variabel hari perdagangan Jum'at diketahui bahwa Nilai t hitung variabel Jum'at sebesar 1.091(t hitung < t tabel) dan nilai signifikan 0.277> 0,05 , maka secara parsial variabel hari perdagangan Jum'at tidak berpengaruh terhadap Return Saham sehingga dapat disimpulkan bahwa penelitian ini $\mathrm{H}_{\mathrm{a} 5}$ dan menerima $\mathrm{H}_{05}$

\section{Pembahasan \\ Pengaruh Hari Perdagangan Terhadap Return Saham}

Day of the week effect merupakan fenomena yang menggambarkan adanya perbedaan return saham yang signifikan pada hari tertentu dengan hari perdagangan lainnya dalam seminggu.

Hasil dari uji signifian parsial (Uji t) untuk hari perdaganagan Selasa menunjukkan bahwa hari perdaganagan Selasa, Rabu dan Jumat tidak berpengaruh terhadap return saham, hal ini dapat dilihat dari tingkan signifikan hari perdaganagan selasa yang lebih besar daripada 0,05 dan nilai $t_{\text {hitung }}$ lebih kecil dari nilai $t_{\text {tabel }}$. Dengan demikian dapat disimpulkan bahwa penelitian ini menolak $\mathrm{H}_{\mathrm{a}}$ dan menerima $\mathrm{H}_{0}$, yang menyatakan bahwa hari perdaganagan Selasa, Rabu, dan Jumat tidak berpengaruh terhadap return saham. Hanya hari perdaganagan Kamis yang berpengaruh secara signifikan terhadap return saham hal ini ditunjukkan oleh nilai signifikan hari Kamis yang lebih kecil daripada 0,05 dan nilai $t_{\text {hitung }}$ lebih besar dari nilai $t_{\text {tabel }}$ sehingga dapat disimpulkan bahwa hari perdagangan Kamis menerima $\mathrm{H}_{\mathrm{a}}$ dan menolak $\mathrm{H}_{0}$. 
Hari Kamis memiliki rata-rata return tertinggi dan memberikan pengaruh positif dan signifikan, hal ini membuktikan terjadinya pengaruh day of the week effect pada saham JII periode Juni 2016 sampai Mei 2017 dengan pengaruh signifikan hari kamis atau disebut Trursday Effect. Hal ini sejalan dengan penelitian yang dilakukan Trisnadi dan Sedana (2016) pada saham LQ-45 yang menemukan bahwa hari kamis berpengaruh secara signifikan terhadap return saham.

Pengaruh positif hari perdagangan Kamis yang signifikan dapat disebabkan oleh tindakan agresif investor dalam bertransaksi setelah memperoleh informasi-informasi dan menyusun strategi investasi. Sebagian investor memanfaatkan awal minggu untuk mengkaji berbagai informasi yang relevan sehingga investor akan menunda transaksi jual beli saham terlebih dahulu. Peningkatan rata-rata return pada hari Kamis kemungkinan disebabkan karena pada hari tersebut investor mulai menerapkan strategi investasi dengan membeli saham yang sudah dianalisis sebelumnya. Apabila dilihat dan ditinjau dari segi psikologis dan perilaku, investor lebih menyukai akhir minggu dan memiliki kecenderungan kurang bertransaksi pada awal minggu. Mood investor yang lebih baik dan optimisme di akhir pekan seperti hari Kamis akan menyebabkan aktivitas perdagangan untuk membeli saham lebih tinggi.

\section{PENUTUP}

\subsection{Kesimpulan}

Berdasarkan hasil analisis data dan pembahasan yang sudah diuraikan dapat ditarik kesimpulan sebagai berikut.

1. Hasil Pengujian menunjukkan bahwa hipotesis pertama dalam penelitian ini tidak terdukung. Hari perdagangan Senin merupakan excluded variable yaitu variabel yang dikeluarkan dari analisis karena memiliki nilai yang ekstrimyaitu nilai tolerance dari variabel hari Senin sangat kecil dan bernilai negatif.

2. Hasil pengujian pada hari perdagangan Selasa menunjukkan bahwa hari perdagangan Selasa memberikan pengaruh negatif dan tidak signifikan, berdasarkan pengujian tersebut maka dapat dibuktikan bahwa hipotesis ke dua tidak terdukung, atau dapat dikatatakan bahwa hari perdagangan Selasa tidak berpengaruh terhadap return saham.

3. Hasil pengujian menunjukkan bahwa hari perdagangan Rabu memberikanpengaruh positif terhadap return saham namun pengaruhnya tidaksignifikan. Berdasarkan hasil pengujian tersebut, maka dapat dibuktikanhipotesis ketiga tidak terdukung, atau dapat dikatakan bahwa hariperdagangan Rabu tidak berpengaruh terhadap return saham.

4. Hasil pengujian pada hari perdagangan Kamis menunjukkan hasil yangmendukung hipotesis. Hari perdagangan Kamis berpengaruh positif secarasignifikan terhadap return saham.

5. Hasil pengujian menunjukkan bahwa hari perdagangan Jum'at memberikanpengaruh positif terhadap return saham namun pengaruhnya tidaksignifikan. Berdasarkan hasil pengujian tersebut, maka dapat dibuktikan hipotesis kelima tidak terdukung, atau dapat dikatakan bahwa hariperdagangan Jum'at tidak berpengaruh terhadap return saham.

\subsection{Saran}

Berdasarkan hasil dan pembahasan yang telah dipaparkan, maka beberapa hal yang dapat menjadi masukan dalam penelitian ini adalah:

1. Disarankan kepada investor agar memperhatikan dan mempertimbangkan hari perdagangan dalam menyusun strategi transaksi jual beli saham supaya bisa tingkat pengembalian yang optimal. Investor dapat memanfaatkan awal minggu di mana harga saham sedang rendah untuk membeli saham dan melakukan penjualan di akhir minggu untuk mendapatkan keuntungan dari selisih harga saham.

2. Variabel yang digunakan dalam penelitian ini hanya terbatas pada returnsaham realisasi sementara ada banyak variabel dalam pasar modal yangdapat digunakan, misalnya abnormal return, volume perdagangan, volatilitassaham, dan sebagainya. Bagi penelitian selanjutnya diharapkan dapatmempertimbangkan penggunaan variabel lain untuk mengetahui bagaimanapengaruhnya terhadap abnormal return yang dapat memberikan keuntunganlebih pada investor.

\section{DAFTAR PUSTAKA}

Arinda,Masitoh Tabita. (2015). Pengaruh Hari Perdagangan Terhadap ReturnSaham Pada Perusahaan Perkebunan Di BEI, Surabaya: Jurnal Ilmu dan Riset Manajemen Vol 4, Nomor 4, April 2015

Anoraga, Panjidanpakarti, piji.(2006). PengantarPasar Modal.RinekaCipta: Jakarta

Fitria, Dian Nurlaily. (2009). Pengaruh Day Of The WeekEffect Terhadap Return Saham 
Pada Perusahaan YangTerdaftar Islamic Index:. Yogyakarta

Ghozali, I. (2005). Aplikasi Analisis Multivariate Dengan Program SPSS. Semarang: Universitas Diponegoro

Gumanti, TatangAry.

ManajemenInvestasiKonsep,

TeoridanApllikasi. MitraWacana Media: Jakarta

Indrasari, Arumdan Tahar Afrizal (2004). Analisis Pengaruh Day of The Week Effect terhadap Return Saham di Bursa Efek Jakarta. Jurnal Akuntansi dan InvestasiVol. 5 No. 2, hal: 131-146, Juli 2004 ISSN: 1411-6227

Iramanidan A. 2006. StudiTentangPengaruhHariPerdaganga nTerhadapReturnSahampada Bursa Efek Jakarta (BEJ). JurnalAkuntansidanKeuanganvol.8 no. 2november 2006: 63-70.

Janie, D. N. A. (2012). Statistik Deskriptif dan Regresi Linier berganda dengan SPSS. Semarang. University Press: Semarang

Jogiyanto,(2010).TeoriPortofoliodanAnalisisInvest asi.edisiketujuh. BPFE-YOGYAKARTA: Yogyakarta.

Kasdjan, Allan Moechamad Zaennoer.dkk (2017). Analisis Anomali Pasar terhadap Return Saham: The Day Of The Week Effect, Week Four Effect, Dan January Effect.Jurnal Kajian Akuntansi, Vol 1, (1), 2017, 35-44 e2579-9991, p2579-9975

Lutfiaji, (2014). Pengujian The Day of The Week Effect, Week-Four Effect, dan Rogalski Effect Terhadap Return Saham LQ45 di Bursa Efek Indonesia. Skripsi. Fakultas Ekonomi dan Bisnis Universitas Brawijaya: Malang

Pandiangan,Oktavianus.(2009).Analisis Anomali Hari Perdagangan TerhadapReturn Saham Pada Bursa Efek Indonesia:skripsi. Fakultas Ekonomi Universitas sumatera utara: Medan, sumatra utara

Prasetyo,Hari (2006) Analisis Pengaruh Hari Perdagangan Terhadap Return, Abnormal Return, Dan Volatilitas Return
Saham (Studi Pada Lq 45 Periode Januari - Desember 2005). Tesis. Universitas dipenegoro: Semarang

Rita, Mario Rio, (2009) Pengaruh Hari Perdagangan terhadap Return Saham: Jurnal Ekonomi dan BisnisVol. XV No. 2, September 2009:121-134.

Samsul, M. (2006).Pasar Modal danManajemenPortofolio.Erlangga: Jakarta.

Saputro, Aditya Probo (2014). Day Of The Week Effect Dan Month Of The Year Effect Terhadap Return Indeks Pasar.Jurnal Nominal / Volume III Nomor 2

Saraswati ,Yunisa Rahardian, (2015). Pengaruh The Day Of The Week Effect, Week Four Effect dan Rogalsky Effect terhadap Return Saham Lq-45 di Bursa Efek Indonesia: Jurnal Riset Akuntansi dan Perpajakan JRAP Vol. 2, No. 1, Juni 2015, hal 43 - 54ISSN 2339 - 1545

Sugiono.(2009). MetodePenelitianBisnis.Alfabeta: Bandung

Trisnadi, Margareta Maria dan Sedana, Ida Bagus Panji.(2016). Pengujian Anomali Pasar : Day Of The Week Effect Pada Saham LQ-45 Di Bursa Efek Indonesia: EJurnal Manajemen Unud,Vol. 5, No. 6, 2016: $3794-3820$ 
